\title{
Length-weight relationships of fishes caught by stationary uncovered pound nets in the coastal waters of Saros Bay, North Aegean Sea (Turkey)
}

\section{Saros Körfezi'nin (Kuzey Ege Denizi) kıyısal sularında ağ dalyan ile yakalanan balıkların boy-ağırlık ilişkileri}

\author{
Serhat Çolakoğlu \\ Çanakkale Onsekiz Mart University, Çanakkale Vocational of Technical Sciences, 17020, Çanakkale, Turkey \\ (D) https://orcid.org/0000-0003-3526-6477 \\ serhat_colakoglu@comu.edu.tr \\ Received date: 14.01 .2020 \\ Accepted date: 18.05 .2020 \\ How to cite this paper: \\ Çolakoğlu, S. (2021). CPUE comparison of traditional crayfish fyke net rigged with knotted net and alternatively knotless net. Ege Journal of Fisheries and \\ Aquatic Sciences, 38(1), 95-99. DOI: 10.12714/egejfas.38.1.11
}

Abstract: Stationary uncovered pound nets are passively fishing gears used for fish catching according to traditional methods in the coastal waters of Saros Bay, North Aegean Sea. The purpose of this study was to determine length-weight relations (LWRs) for a wide range of fish species collected from the traps in the coastal waters of Saros Bay. We are studied in the fish species caught by four traps between April and August (fishing season) in 2010 - 2012. A total of 23 fish species belonging to 12 families were caught individual 2.096 . The mean value of the growth pattern $(b)$ was $3.141 \pm 0.042$, ranging from 2.711 to 3.577. Whereas they were negative allometric only for two species (Pomatomus saltatrix and Mugil cephalus), from other fish species were observed to be 13 positive allometric and 8 isometrics. The LWR parameters for the positive allometric and isometric fish species were significant $(P<0.05)$. This study provides some general information about the status of the LWR parameters of the fish species caught from the traps.

Keywords: Length- weight relationship, fish species, stationary uncovered pound net, Saros Bay

Öz: Ağ dalyanlar, Kuzey Ege Denizi'nin Saros Körfezi kıyılarında geleneksel yöntemlere göre balık avlamada kullanılan pasif av araçlarıdır. Bu çalışmanın amacı, Saros Körfezi kıyılarındaki ağ dalyanlardan toplanan çeşitli balık türleri için boy-ağırlık ilişkilerini (LWRs) belirlemektir. 2010 - 2012 yıllarında Nisan ve Ağustos ayları arasında (balık avlama sezonu) dört ağ dalyandan yakalanan balık türlerinde çalışıııștı. 12 aileye ait toplam 23 balık türünde toplam 2.096 adet birey yakalandı. Büyüme ilişkilerinin (b) ortalama değeri 3,141 $\pm 0,042$ iken, 2,711 - 3,577 arasında değişmiştir. Sadece iki tür (Pomatomus saltatrix ve Mugil cephalus) negatif allometrik iken, diğer balık türlerinden 13 pozitif allometrik ve 8 izometrik olduğu tespit edilmiştir. LWR parametreleri pozitif allometrik ve izometrik balık türleri için anlamlıydı $(P<0,05)$. Bu çalışma, ağ dalyanlardan yakalanan balık türlerinin LWR parametreleri ile ilgili bazı genel bilgiler sunmaktadır.

Anahtar kelimeler: Boy-ağırlık ilişkileri, balık türleri, ağ dalyan, Saros Körfezi

\section{INTRODUCTION}

The stationary uncovered pound net fishery is well known to be one of the oldest methods used in different regions of the world. These fishing systems are established in different types and sizes in shallow waters with sandy-muddy substrates at certain periods of the year (Deveciyan, 2011). These traps are used in the coastal areas of the Mediterranean Sea, the Aegean Sea, and the Marmara Sea in Turkey (Çolakoğlu et al., 2015; Biçer et al., 2020). The stationary uncovered pound net fishery on the coast of Saros Bay is used extensively due to the high commercial value of the fish species (Çolakoğlu et al., 2015; Biçer et al., 2020). There are 15 traps in this region and they are limited to this number by the competent authority. This study is important in terms of determination of species diversity, length, and weight distributions of fishes caught by stationary uncovered pound net in the coastal waters of Saros Bay, North Aegean Sea.

The length-weight relationship (LWR) is of great importance in fisheries biology and population dynamics (Silva et al., 2013). This information is useful for the prediction of indications of condition, level of breeding, feeding, and stock assessment of the fish (YIldı et al., 2018). Also, LWR is used in morphological comparisons of fish species (Gonçalves et al., 1997).

In other studies conducted in Turkey have been made assessment on LWR for fish species caught in the coastal areas of the Black Sea, the Marmara Sea, the Aegean Sea and the Mediterranean Sea (Taskavak \& Bilecenoglu, 2001; Filiz \& Bilge, 2004; Karakulak et al., 2006; Ozaydin \& Taskavak, 2006; Akyol et al., 2007; Demirhan \& Can, 2007; Ismen et al., 2007; Ozaydin et al., 2007; Ilkyaz et al., 2008; Ceyhan et al., 2009; Erguden et al., 2009; Keskin \& Gaygusuz, 2010, Kasapoglu \& Düzgünes, 2014; Yıldız et al., 2018). There is not enough information about species diversity, length and weight distributions of fishes caught by stationary uncovered pound nets in Saros Bay. The present study aimed to characterize the relationship between the length and weight of fish species caught along the sampling period from the stationary uncovered pound net. In addition, 
the results will provide information on the sustainability of the fish caught by traps in the region.

\section{MATERIAL AND METHOD}

Surveys were regularly recorded the fish caught in one day, twice a week for each trap between April and August (stationary uncovered pound net fishing season) in the years 2010-2012 in four locations along the coastal waters of Saros Bay in the North Aegean Sea, Turkey (Figure 1).

Each fisheries system was constructed over a surface area of approximately 0.5 hectares $(70 \mathrm{~m}$ width and $70-80 \mathrm{~m}$ length) at depths of up to 20-30 m, perpendicular to the shore in Saros Bay (Figure 2). The stationary uncovered pound net was located just above the average low tide line and consisted of a leader net, an entrance, a slope, a bag net, and a final trap, and all of them supported by galvanized pipe poles (Çolakoğlu et al., 2015). At each location, the mesh size of all parts of the traps was usually constructed of a $10.5 \mathrm{~mm}$ mesh. Four fishermen recovered the fish caught in the traps by removing the net in both final traps $\left(168 \mathrm{~m}^{2}\right)$. Stationary uncovered pound nets were checked twice daily (at sunrise and sunset) and usually cleared only during low tide.

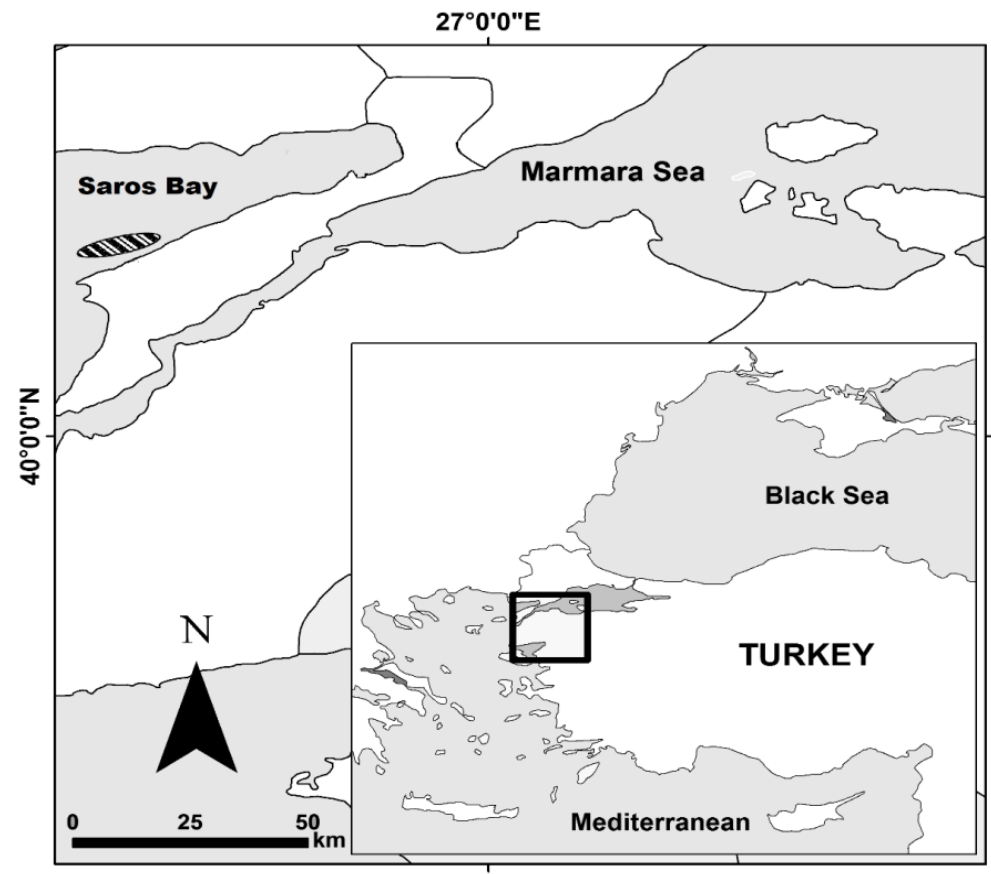

Figure 1. Sampling locations

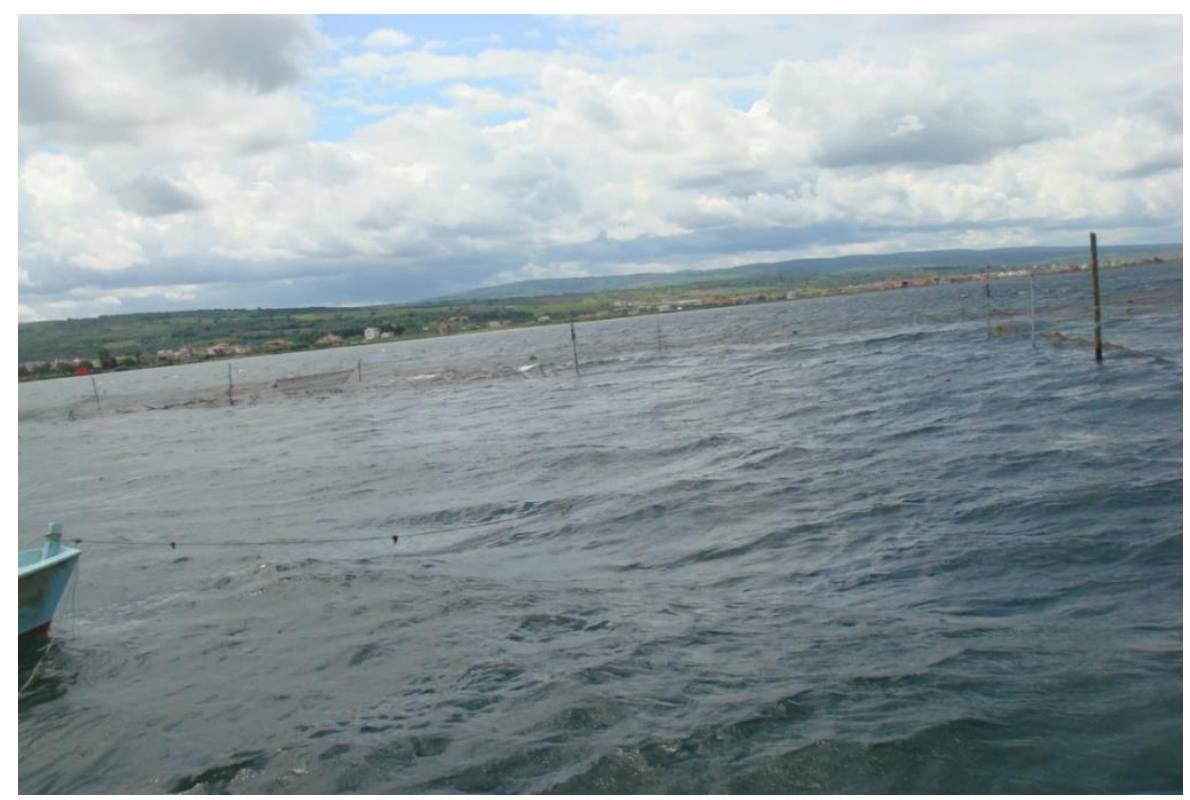

Figure 2. A typically stationary uncovered pound net in Saros Bay 
Samples were packaged in styrofoam boxes and transported with high humidity to the laboratory in 2 hours via an ice-cooled box. All fish species were identified according to Mater et al. (2003), and the scientific name for each species was checked according to the FishBase $®$ (Froese \& Pauly, 2013). The fresh samples total length ( $T L)$ was recorded to the nearest $0.1 \mathrm{~cm}$.

The total weight $(\mathrm{W})$ of each fish was measured using an electronic balance $(0.01 \mathrm{mg}$ accuracy). The fish length and weight relationship were calculated using the exponential relationship: $W=a \times L^{b}$, where $W$ is total weight $(g), L$ is the total length (all data standardized to $\mathrm{cm}$ ), $a$ is the intercept, and $b$ is the slope. Parameters $a$ and $b$ were estimated by least-squares linear regression on log-log transformed data: $(\mathrm{Ln} W=\operatorname{Ln} a+b \times \operatorname{Ln} \mathrm{L})$. The coefficient of determination $\left(\mathrm{R}^{2}\right)$ was used as an indicator of the quality of linear regression. To confirm whether the values of $b$ obtained in the linear regressions were significantly different from the isometric value $(b=3)$ and negative $(b<3)$ or positive $(b>3)$ allometric relationships, t-tests were used. In addition, the functional regression $b$ value represents the body shape as related to the weight (Ricker, 1973). A Student's t-test $(\alpha=0.05)$ was employed to test whether the $b$ value was significantly different from the isometric $(b=3)$ point (Zar, 1999). Student ttests and ANCOVA were performed using the Statistica $₫ 8.0$ software package (StatSoft, 2007). Descriptive statistics were derived using Microsoft Office Excel 2016 software (Seattle, WA, USA).

\section{RESULTS AND DISCUSSION}

Stationary uncovered pound nets are one of the most important fishing gears used in fishing in Turkey. The trap fishing in different regions of the country is carried out using artisanal methods along the coast of the Aegean and Marmara Seas (Çolakoğlu et al., 2015). Although the LWRs studies in the fishes caught with different fishing gears were made, there are no studies on the fishes caught with traps. In this study, LWRs were determined for the fishes caught with stationary uncovered pound nets in the coastal waters of Saros Bay, North Aegean Sea.

During the research period, a total of 23 species belonging to 12 families were caught 2.096 individuals in total by the traps. The dominant within the caught fish species were components of Trachurus mediterraneus (19.08\%), Sardinella aurita (15.08\%), Boops boops (8.54\%), Oblada melanura (6.92\%), and Sardina pilchardus (6.54\%) and which represented approximately $56.15 \%$. Minimum and maximum lengths, weights, parameters of the LWRs and standard errors of $b$ values for 23 species were summarized in Table 1. According to the results of the present study, the slope $b$ values ranged between $2.711 \pm 0.017$ (Mugil cephalus) and $3.577 \pm 0.008$ (Scomber japonicus), and a values ranged from 0.0004 (Belone belone) to 0.0216 (M. cephalus) $(\mathrm{P}<0.05)$. Whereas they were negative allometric only for two species (Pomatomus saltatrix and M. cephalus), from other fish species were observed to be 13 positive allometric and 8 isometrics. The LWR parameters for the positive allometric and isometric fish species were significant $(P<0.05)$. The highest $b$ value was over the upper limit for only two species S. japonicus (3.577) and Diplodus annularis (3.417). The LWRs were significant for all species, with $R^{2}$ values ranging from 0.823 (Scomber scombrus) to 0.993 (Sarpa salpa) $(P<0.05)$ (Table 1).

A comparison of the $b$ values between the present study and other studies is shown in Table 2.

Table 1. The results of length-weight relationships of fish species caught from the coastal waters of Saros Bay, North Aegean Sea

\begin{tabular}{|c|c|c|c|c|c|c|c|c|c|c|c|}
\hline \multirow[b]{2}{*}{ Family } & \multirow[b]{2}{*}{ Species } & \multirow[b]{2}{*}{$\mathbf{n}$} & \multicolumn{2}{|c|}{ Length } & \multicolumn{2}{|c|}{ Weight } & \multicolumn{4}{|c|}{ Relationship parameters } & \multirow{2}{*}{$\begin{array}{c}\text { Range of } b \\
\text { Fishbase }\end{array}$} \\
\hline & & & Mean ( \pm SD) & $\begin{array}{l}\text { Range } \\
\text { (cm) }\end{array}$ & \pm ISD) & Range (g) & a & $b$ & SE (b) & $\mathbf{R}^{2}$ & \\
\hline Carangidae & Trachurus mediterraneus & 400 & $17.22 \pm 1.97$ & $11.0-24.6$ & $45.56 \pm 16.26$ & $10.1-121.1$ & 0.0090 & 2.982 & 0.004 & 0.949 & $2.964-3.573$ \\
\hline \multirow{6}{*}{ Clupeidae } & Sardinella aurita & 316 & $20.65 \pm 1.84$ & $15.8-26.2$ & 66.03 & 34.0 & 0.0069 & 3.020 & 0.004 & 0.907 & 3.660 \\
\hline & Sardina pilchardus & 137 & $15.18 \pm 1.54$ & $11.5-17.5$ & $28.42 \pm 8.36$ & $10.0-43.0$ & 0.0036 & 3.280 & 0.007 & 0.945 & $3.257-3.621$ \\
\hline & Spondyliosoma cantharus & 120 & $17.95 \pm 3.07$ & $12.0-30.8$ & $102.96 \pm 73.50$ & $21.9-563.0$ & 0.0080 & 3.238 & 0.013 & 0.943 & $3.123-4.159$ \\
\hline & & 179 & $17.42 \pm 3.24$ & $12.1-25.5$ & & & 0.0115 & 2.936 & 0.010 & 0.973 & \\
\hline & Oblada melanura & 145 & $23.59 \pm 3.62$ & $14.7-30.0$ & $179.65 \pm 85.73$ & $19.10-360.0$ & 0.0056 & 3.263 & 0.015 & 0.984 & $2.904-4.081$ \\
\hline & Sarpa salpa & 52 & $17.44 \pm 4.31$ & $13.7-29.4$ & 73.89 & & 0.0105 & 3.059 & 0.025 & 0.993 & $3.232-3.839$ \\
\hline \multirow{5}{*}{ Sparidae } & Page & 51 & $14.97 \pm 2.28$ & $12.5-21.5$ & & & 0.0108 & 3.076 & 0.015 & 0.976 & 3.638 \\
\hline & Diplodus annularis & 23 & $15.27 \pm 1.69$ & $11.4-19.8$ & $67.76 \pm 27.66$ & $23.0-154.0$ & 0.0058 & 3.417 & 0.020 & 0.969 & $3.478-3.912$ \\
\hline & Pagellus acarne & 21 & $18.14 \pm 2.89$ & $13.5-24.6$ & $82.56 \pm 44.40$ & & 0.0084 & 3.142 & 0.028 & 0.972 & $3.309-3.780$ \\
\hline & Lithognathus mormyrus & 20 & 23.3 & $19.3-28.5$ & 577.16 & & 0.0040 & 3.373 & 0.033 & 0.981 & .912 \\
\hline & Scomber & 121 & 23.0 & $17.5-30.0$ & $113.72 \pm 40.37$ & 38. & 0.0015 & 3.577 & 0.008 & 0.953 & $3.852-4.350$ \\
\hline \multirow[t]{2}{*}{ Scombridae } & Scomber scombrus & 54 & $28.01 \pm 1.09$ & $23.3-30.0$ & $184.24 \pm 24.96$ & $103.0-252.0$ & 0.0041 & 3.209 & 0.006 & 0.823 & $3.759-4.024$ \\
\hline & & 15 & 47.3 & $39.2-67.0$ & 1358 & 671 & 0.0072 & 3.102 & 0.082 & 0.986 & 692 \\
\hline \multirow{2}{*}{ Centracanthidae } & Spicara smaris & 86 & .99 & $10.7-19.0$ & 28.22 & $11.0-55.1$ & 0.0106 & 2.942 & 0.010 & 0.974 & 3.285 \\
\hline & Spicara maena & 48 & $16.91 \pm 1.46$ & $13.5-19.8$ & $65.90 \pm 17.20$ & $31.0-99.0$ & 0.0086 & 3.154 & 0.011 & 0.953 & $3.319-3.619$ \\
\hline $\mathrm{P}$ & Pomatomus salta & 73 & & $19.5-33.3$ & & & 0.0148 & 2.807 & 0.014 & 0.979 & $3.204-3.710$ \\
\hline Sphyr & hrysotaenia & 65 & 27 & $24.8-38.9$ & 1.71 & & 0.0012 & 3.308 & 0.012 & 0.951 & 4.178 \\
\hline Belonidae & Belone belone & 58 & $42.69 \pm 6.44$ & $29.1-55.0$ & $81.18 \pm 42.38$ & $25.0-175.0$ & 0.0004 & 3.263 & 0.018 & 0.945 & $3.719-4.214$ \\
\hline Engraulidae & Engraulis encrasicholus & 36 & $14.33 \pm 0.91$ & $11.7-15.6$ & $20.47 \pm 3.87$ & $11.0-2$ & 0.0053 & 3.096 & 0.008 & 0.924 & $3.162-3.359$ \\
\hline Mugilid & Mugil c & 25 & 2.06 & $27.0-34.2$ & 47.42 & 155. & 0.0216 & 2.711 & 0.017 & 0.882 & $3.349-3.630$ \\
\hline Atherinid & Atherina boyeri & 22 & 12.28 & $11.2-14.0$ & & & 0.0066 & 3.014 & 0.014 & 0.839 & $3.032-3.203$ \\
\hline Scorpaenidae & Scorpaena scrofa & 19 & $24.81 \pm 4.78$ & $18.3-34.0$ & $381.89 \pm 244.93$ & $121.0-896.0$ & 0.0094 & 3.266 & 0.063 & 0.972 & $3.688-4.276$ \\
\hline
\end{tabular}


Table 2. Comparison of length-weight relationship parameters for fish species obtained by several researchers

\begin{tabular}{|c|c|c|c|c|c|c|c|c|c|c|c|c|c|c|c|c|c|c|c|}
\hline \multirow[t]{2}{*}{ Species } & \multicolumn{3}{|c|}{ This study (7) } & \multicolumn{4}{|c|}{ The Dardanelles } & \multicolumn{3}{|c|}{$\begin{array}{lc}\text { Saros } & \text { Bay } \\
\text { Gökçeada Island }\end{array}$} & \multicolumn{4}{|c|}{ and Marmara Sea } & \multicolumn{4}{|c|}{ Black Sea } & \multirow[b]{2}{*}{ Ref. } \\
\hline & $\mathrm{N}$ & a & b & $\mathbf{N}$ & a & $b$ & Ref. & $\mathrm{N}$ & a & $b$ & Ref. & $\mathbf{N}$ & a & $b$ & Ref. & $\mathbf{N}$ & a & $b$ & \\
\hline Atherina boyeri & 22 & 0.007 & 3.01 & - & - & - & - & - & - & - & - & 14 & 0.002 & 3.49 & 4 & - & - & - & - \\
\hline Belone belone & 58 & 0.003 & 3.26 & & & & & 30 & 0.001 & 3.19 & 1 & - & - & - & - & - & - & - & - \\
\hline Boops boops & 179 & 0.012 & 2.94 & - & - & - & - & 189 & 0.005 & 3.24 & 2 & - & - & - & - & - & - & - & - \\
\hline Diplodus annularis & 23 & 0.006 & 3.42 & 282 & 0.015 & 3.05 & 1 & 108 & 0.016 & 3.02 & 2 & 15 & 0.022 & 2.96 & 4 & - & - & - & - \\
\hline Engraulis encrasicholus & 36 & 0.005 & 3.10 & - & - & - & - & - & - & - & - & - & - & - & - & 1588 & 0.013 & 2.71 & 6 \\
\hline Lithognathus mormyrus & 20 & 0.004 & 3.37 & 45 & 0.019 & 2.86 & 1 & - & - & - & - & - & - & - & - & - & - & - & - \\
\hline Mugil cephalus & 25 & 0.022 & 2.71 & - & - & - & - & - & - & - & - & - & - & - & - & - & - & - & - \\
\hline Oblada melanura & 145 & 0.006 & 3.26 & 97 & 0.018 & 2.89 & 1 & 316 & 0.003 & 3.46 & 3 & - & - & - & - & - & - & - & - \\
\hline Pagellus acarne & 21 & 0.008 & 3.14 & 228 & 0.012 & 3.03 & 1 & - & 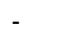 & - & - & - & - & - & - & - & - & - & - \\
\hline Pagellus bogaraveo & 51 & 0.011 & 3.08 & 92 & 0.024 & 2.78 & 1 & 2355 & 0.007 & 3.19 & 2 & - & - & - & - & - & - & - & - \\
\hline Pomatomus saltatrix & 73 & 0.015 & 2.81 & - & - & - & - & - & - & - & - & 290 & 0.033 & 2.53 & 4 & 25 & 0.009 & 3.01 & 6 \\
\hline Sarda sarda & 15 & 0.007 & 3.10 & & - & - & 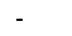 & - & - & - & - & - & - & - & 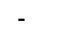 & 36 & 0.050 & 2.56 & 6 \\
\hline Sardinella aurita & 316 & 0.007 & 3.02 & 26 & 0.001 & 3.28 & 1 & 50 & 0.006 & 3.07 & 3 & 24 & 0.003 & 3.44 & 5 & - & - & - & - \\
\hline Sardina pilchardus & 137 & 0.004 & 3.28 & 146 & 0.006 & 3.12 & 1 & - & - & - & - & - & - & - & - & - & - & - & - \\
\hline Sarpa salpa & 52 & 0.011 & 3.06 & 99 & 0.013 & 3.02 & 1 & - & - & - & - & - & - & - & - & - & - & - & - \\
\hline Scomber japonicus & 121 & 0.002 & 3.58 & 69 & 0.004 & 3.23 & 1 & 45 & 0.002 & 3.52 & 2 & - & - & - & - & - & - & - & - \\
\hline Scomber scombrus & 54 & 0.004 & 3.21 & 58 & 0.006 & 3.08 & 1 & 100 & 0.003 & 3.29 & 2 & - & - & - & - & - & - & - & - \\
\hline Scorpaena scrofa & 19 & 0.009 & 3.27 & 134 & 0.022 & 2.96 & 1 & 15 & 0.018 & 3.00 & 3 & . & - & - & - & & - & - & - \\
\hline Spicara maena & 48 & 0.009 & 3.15 & - & - & - & - & 353 & 0.0098 & 3.01 & 2 & - & - & - & - & - & - & - & - \\
\hline Spicara smaris & 86 & 0.011 & 2.94 & 114 & 0.011 & 3.01 & 1 & 1449 & 0.012 & 2.91 & 2 & 403 & 0.009 & 3.08 & 4 & 103 & 0.022 & 2.72 & 6 \\
\hline Sphyraena chrysotaenia & 65 & 0.001 & 3.31 & - & - & - & - & - & - & - & - & - & - & - & - & - & - & - & - \\
\hline $\begin{array}{l}\text { Spondyliosoma } \\
\text { cantharus }\end{array}$ & 120 & 0.008 & 3.24 & 156 & 0.008 & 3.26 & 1 & 45 & 0.009 & 3.17 & 2 & - & - & - & - & - & - & - & - \\
\hline $\begin{array}{l}\text { Trachurus } \\
\text { mediterraneus }\end{array}$ & 400 & 0.009 & 2.98 & 489 & 0.006 & 3,13 & 1 & 446 & 0.0032 & 3.37 & 2 & 307 & 0.006 & 3.13 & 4 & 624 & 0.005 & 3.14 & 6 \\
\hline
\end{tabular}

Ref. is the reference of different researchers: 1: Cengiz, (2013); 2: Ismen, A. et al., (2007); 3: Karakulak et al., (2006); 4: Bok et al., (2011); 5: Keskin and Gaygusuz, (2010); 6: Kasapoglu and Duzgunes, (2014); 7: Present study.

Parameter $b$ (2.98) for $T$. mediterraneus in this study was lower than the one obtained from the Aegean Sea 3.37 (Ceyhan et al., 2009) and the Black Sea (3.14) (Kasapoglu \& Duzgunes, 2014) and (3.17) (Yankova et al., 2011), the Dardanelles (3.13) (Cengiz, 2013), the Saros Bay (3.37) (İsmen et al., 2007), but higher than from the Mediterranean Sea (2.81) (Sangun et al., 2007). The $b$ coefficient (3.02) value obtained for $S$. aurita was found to be similar to the values of the same species studied for the North Aegean Sea (3.07) (Karakulak et al., 2006) and smaller than for the Dardanelles (3.28) (Cengiz, 2013). b (3.26) for Oblada melanura was found to be lower than the findings obtained in the North Aegean Sea (3.46) (Karakulak et al., 2006), but higher than in the Dardanelles (2.89) (Cengiz, 2013). b (3.58) for $S$. japonicus was found to be similar to the findings obtained in the Saros Bay (3.52) (Işsmen et al., 2007), but higher than in the Dardanelles (3.23) (Cengiz, 2013) and the North Aegean Sea (3.10) (Karakulak et al., 2006). b (3.24) for Spondyliosoma cantharus was found to be similar to the findings obtained in the Dardanelles (3.26) (Cengiz, 2013) and the Saros Bay (3.17) (İşmen et al., 2007), but higher than in the North Aegean Sea (2.87) (Karakulak et al., 2006). b value (2.94) for $B$. boops was found to be lower than the findings obtained in the Saros Bay (3.24) (Iş̧men et al., 2007). $b$ values for Spicara maena (3.15) and D. annularis (3.42) in the present study were found to be higher than the findings obtained (3.01 and 3.02) in the Saros Bay, respectively (Iş̧men et al., 2007). The study conducted by İşmen et al. (2007) with this study was observed that of differences in $b$ values in some fish species. The reason for this is thought to be due to the low number of samples and the difference of the fishing gear. In addition, the low number of samples in 7 different fish species in the study can decrease the reliability of the results.

The differences in LWR parameters of the fishes investigated in studies could be caused by factors such as lack or abundance of food, specimens age, reproductive stage and sex characteristics (Wootton, 1990), number of specimens analyzed, ecological differences of the sampling areas, sampling duration (Moutopoulos \& Stergiou, 2002), fishing gear used and selectivity (İşmen et al., 2007; Cengiz, 2013). The relationship between $a$ and $b$ is an important factor influencing the body shape of fishes (Froese, 2006) and these factors can be used to assess the 'well-being' of individual fish (Jobling, 2002).

In conclusion, the results of this study could be used as a reference for comparing the findings of other studies. Additionally, results from this study also provide basic information that may facilitate conservation and stock management policies of the impact on fish species of stationary uncovered pound nets fishing conducted in the coastal waters of Saros Bay. 


\section{REFERENCES}

Akyol, O., Kinacigil, H.T. \& Sevik, R. (2007). Longline fishery and lengthweight relationships for selected fish species in Gokova Bay (Aegean Sea, Turkey). International Journal of Natural and Engineering Sciences, $1,1-4$.

Biçer, D., Yıldı, T., Uzer, U., Karakulak, F.S. (2020). Last dalians (stationary uncovered pound nets) deployed in the İstanbul Strait: Catch composition, catch per unit effort, and ecological indexes. Ege Journal of Fisheries and Aquatic Sciences 37(2), 125-133.

Bok, T.D., Gokturk, D., Kahraman, A.E., Alıclı, T.Z., Acun, T. \& Ateş, C. (2011). Length-weight relationships of 34 fish species from the Sea of Marmara, Turkey. Journal of Animal and Veterinary Advances, 10 (23): 3037-3042. DOI: 10.3923/javaa.2011.3037.3042

Cengiz, Ö. (2013). Length-weight relationships of 22 fish species from the Gallipoli Peninsula and Dardanelles (northeastern Mediterranean, Turkey). Turkish Journal of Zoology, 37: 419-422. DOi:10.3906/zoo-1209-30

Ceyhan, T., Akyol, O. \& Erdem, M. (2009). Length-weight relationships of fishes from Gokova Bay, Turkey (Aegean Sea). Turkish Journal of Zoology, 33: 69-72.

Çolakoğlu, S., Tokaç, A., İşmen, A. \& Yurdusev, H. (2015). Catch composition of set net (fixed stake trap) fisheries in the coastal waters of Saros Bay, North Aegean Sea. Ege Journal of Fisheries Aquatic Science 32(2): 53-58. DOI: 10.12714/egejfas.2015.32.2.02

Demirhan, S.A. \& Can, M.F. (2007). Length-weight relationships for seven fish species from the southeastern Black Sea. Journal of Applied Ichthyology, 23: 282-283. DOI:10.1111/j.14390426.2007.00835.x

Deveciyan, K. (2011). Türkiye'de Balık ve Balıkçılık. Aras Yayıncılık, İstanbul, 2011.

Erguden, D., Turan, C. \& Gurlek, M. (2009). Weight-length relationships for 20 lessepsian fish species caught by bottom trawl on the coast of Iskenderun Bay (NE Mediterranean Sea, Turkey). Journal of Applied Ichthyology, 25: 133-135. DOI: 10.1111/j.1439-0426.2008.01198.x

Filiz, H. \& Bilge, B. (2004). Length-weight relationships of 24 fish species from the North Aegean Sea, Turkey. Journal of Applied Ichthyology, 20: 431-432. DOI: 10.1111/j.1439-0426.2004.00582.x

Froese, R. (2006). Cube law, condition factor and weight-length relationships: history, meta-analysis and recommendations. Journal of Applied Ichthyology, 22: 241-253. DOI: $10.1111 /$ j.1439-0426.2006.00805.x

Froese, R. \& Pauly, D. (2013). FishBase. World Wide Web electronic publication. www. fishbase.org (10/2013).

Gonçalves, J.M.S., Bentes, L., Lino, P.G., Ribeiro, J., Canário, A.V.M. \& Erzini, K. (1997). Weight-length relationships for selected fish species of the small-scale demersal fisheries of the South and southwest coast of Portugal. Fisheries Research, 30, 253-256.

Ilkyaz, T., Metin, G., Soykan, O. \& Kinacigil, H.T. (2008). Length-weight relationship of 62 fish species from the Central Aegean Sea, Turkey. Journal of Applied Ichthyology, 24, 699-702. DOI: 10.1111/j.1439-0426.2008.01167.x

Ismen, A., Ozen, O., Altinagac, U., Ozekinci, U. \& Ayaz, A. (2007). Weightlength relationships of 63 fish species in Saros Bay, Turkey. Journal of Applied Ichthyology, 23, 707-708. DOI: 10.1111/j.1439-0426.2007.00872.x
Jobling, M. (2002). Environmental factors and rates of development and growth. In: Handbook of fish biology and fisheries (P.J.B. Hart \& J.D. Reynolds eds). Pp. 97-122. Blackwell Science Ltd: Oxford, USA.

Karakulak, F.S., Erk, H. \& Bilgin, B. (2006). Length-weight relationships for 47 coastal fish species from the northern Aegean Sea, Turkey. Journal of Applied Ichthyology, 22, 274-278.

DOI: $10.1111 /$ j.1439-0426.2006.00736.x

Kasapoglu, N. \& Duzgunes, E. (2014). Length-weight relationships of marine species caught by five gears from the Black Sea. Mediterranean Marine Science, 15, 95-100. DOI:10.12681/mms.463

Keskin, C. \& Gaygusuz, O. (2010). Length-weight relationships of fishes in shallow waters of Erdek Bay (Sea of Marmara, Turkey). IUFS Journal of Biology, 69 (1), 25-32.

Mater, S., Kaya, M. \& Bilecenoğlu, M. (2003). Türkiye Deniz Balıkları Atlası (III. Baskı), Ege Üniversitesi Su Ürünleri Fakültesi Yayınları, No. 68, İmir (In Turkish),169p.

Moutopoulos, D.K. \& Stergiou, K.I. (2002). Length-weight and length-length relationships of fish species from the Aegean Sea (Greece). Journal of Applied Ichthyology, 18, 200-203. DOI: 10.1046/j.1439-0426.2002.00281.x

Ozaydin, O. \& Taskavak, E. (2006). Length-weight relationships for 47 fish species from Izmir Bay (eastern Aegean Sea, Turkey). Acta Adriatica, 47, 211-216.

Ozaydin, O., Uckun, D., Akalin, S., Leblebici, S. \& Tosunoglu, Z. (2007). Length-weight relationships of fishes captured from Izmir Bay, Central Aegean Sea. Journal of Applied Ichthyology, 23, 695-696. DOI: 10.1111/j.1439-0426.2007.00853.x

Ricker, W.E. (1973). Linear regressions in fishery research. Journal of the Fisheries Research Board of Canada, 30, 409-434.

Sangun, L., Akamca, E. \& Akar, M. (2007). Weight-length relationships for 39 fish species from the north-eastern Mediterranean coast of Turkey. Turkish Journal of Fisheries and Aquatic Sciences, 7, 37-40.

Silva, J.F., Ellis, J.R. \& Ayers, R.A. (2013). Length-weight relationships of marine fish collected from around the British Isles. Science Series Technical Report $n^{\circ} 150$. Cefas: Lowestoft. 109 pp.

StatSoft, Inc. (2007). STATISTICA (data analysis software system), version 8.0.

Taskavak, E. \& Bilecenoglu, M. (2001). Length-weight relationships for 18 lessepsian (Red Sea) immigrant fish species from the eastern Mediterranean coast of Turkey. Journal of the Marine Biological Association of the United Kingdom, 81, 895-896. DOI: 10.1017/S0025315401004805

Wootton, R.J. (1990). Ecology of Teleost Fish. Chapman and Hall, London. 404p.

Yankova, M., Pavlov, D., Raykov, V., Michneva, V. \& Radu, G. (2011). Length-Weight Relationships of Ten Fish Species from the Bulgarian Black Sea waters. Turkish Journal of Zoology, 35, 265-270.

Yıldız, T., Zengin, M., Uzer, U., Akpınar, I..̈. \& Karakulak, F.S. (2018). Length-weight relationships for 24 fish species collected from the western Black Sea (Turkey). Cahiers de Biologie Marine, 59,159-165. DOI: 10.21411/CBM.A.39436D05

Zar, J.H. (1999). Biostatistical Analysis. 4thedition. Prentice Hall: Englewood Cliffs, New Jersey. 929 pp. 